\title{
光ファイバによる20MWレーザーパルスの伝送とその応用
}

依田 正樹, 佐野 雄二, 向井 成彦, Thomas SCHMIDT-UHLIG *, Gerd MAROWSKY*

(株) 東芝電力・産業システム技術開発センター（テ235-8523 横浜市磯子区新杉田町8）

*ゲッティンゲン・レーザー研究所 (Hans-Adolf-Krebs-Weg 1, 37077 Göttingen, Germany)

\section{Fiber Delivery of 20 MW Laser Pulses and Its Applications}

\author{
Masaki YODA, Yuji SANO, Naruhiko MUKAI, Thomas SCHMIDT-UHLIG, * \\ and Gerd MAROWSKY* \\ Power \& Industrial Systems Research \& Development Center, Toshiba Corporation, \\ 8 Shinsugita, Isogo, Yokohama, Kanagawa 235-8523 \\ * Laser Laboratorium Göttingen e.V. , Hans-Adolf-Krebs-Weg 1, 37077 Göttingen, Germany
}

(Received January 11, 2000)

\begin{abstract}
The authors delivered $20 \mathrm{MW}$ laser pulses through an optical fiber with a core diameter of $1.5 \mathrm{~mm}$ and a length of $5 \mathrm{~m}$, using a beam homogenizer which divided laser beam into $7 \times 7$ squares and folded it up into a single square of $0.81 \times 0.81 \mathrm{~mm}$ at the front entrance of the fiber. The laser pulses, which were emitted from a frequency-doubled Nd:YAG laser with an energy of $138 \mathrm{~mJ}$ and a pulse duration of $5 \mathrm{~ns}$, were irradiated to the all silica step index multi-mode fiber via the homogenizer. The peak intensity of laser pulses reached $42 \mathrm{TW} /$ $\mathrm{m}^{2}\left(4.2 \mathrm{GW} / \mathrm{cm}^{2}\right)$ at the fiber entrance. As an example of practical applications, we demonstrated the feasibility of fiber-delivered laser peening through experiments in which the residual stress of an SUS304 test sample was improved from tensile to compressive.
\end{abstract}

Key Words: Pulse laser, Fiber delivery, Beam homogenizer, Laser peening

\section{1. 諸 言}

光ファイバは, 低損失・大容量で構造が柔軟であるなど の優れた特徵により光通信をはじめとする様々な分野で 適用されている。大出力レーザーによる加工分野におい ても, $\mathrm{kW}$ 級出力のCW発振YAGレーザーを用いた溶接, 切 断あるいは表面改質のためのレーザー光伝送に石英系 ファイバが利用されている。しかし, 高出力のパルス発振 レーザーに関しては,ピーク出力が大きいため光ファイバ の損傷が発生し伝送エネルギーをあまり大きくできない のが現状であった. 最近ではパルスNd:YAGレーザー光の 伝送に中空ファイバを用いる試みがなされており1)成果が 期待される.

本稿では, 石英ファイバの損傷メカニズムの検討結果か ら採用したビームホモジナイザを利用した入射光学系の 原理と,この入射光学系を用いた石英ファイバによるピー ク出力20MWのパルス Nd:YAGレーザー光の伝送試験につ いて述べる。また，その応用についてレーザーピーニング を中心に述べる。
2. パルスレーザーの光ファイバ伝送

2.1 光ファイバの損傷メカニズム

単純に単レンズで集光してパルスレーザー光を光ファ イバに入射した場合, 最大伝送エネルギーはレーザー発振 器や周囲の条件により大きく左右される. 筆者らの経験 ではコア径 $1 \sim 1.5 \mathrm{~mm}$ 程度の石英ファイバを用いて $\mathrm{Nd}$ : YAGレーザーの第2高調波(波長532nm, パルス幅5ns, 繰り 返し $10 \mathrm{~Hz}$ )を伝送すると10３0mJ程度のパルスエネルギー で入射端面付近に損傷が発生した。 また, 空気中において 単レンズで集光すると入射端面手前の焦点でエアーブレ イクダウンが発生しエネルギーの大幅なロスが生じた。

パルスレーザーに対する光ファイバの耐久性はレー ザー光の波長やパルス幅, 材料の材質や表面状態によって 異なるが, 光ファイバの損傷は高エネルギー密度のレー ザー光とコア材質の相互作用により多光子電離や電子な だれが発生し引き起こされる。高出力レーザーの伝送に は一般にコアが純粋石英の光ファイバが用いられるが, 損 傷は主に入射端面でのピットの生成や比較的入射端面近 くのコア内部でのクラックの生成に分けられる2).

石英コアの損傷しきい值は内部に比較して表面の方が 小さく,その比は $1 / 3$ 程度との報告もある ${ }^{3,4)}$. 光ファイバ 
の入射端面は内部に比べ研磨傷等の小さな欠陥が起点と なって損傷を発生しやすいことも損傷しきい值を引き下 げる要因の一つと考えられる，従って, 表面の欠陥を極力 なくすことが必要である。また, 入射レーザー光がFig.1 (a)に示すような空間的に強度分布を持つ場合, そのピーク 值で最大伝送エネルギーが制限される。そこで,レーザー 光のエネルギー密度分布をFig.1 (b)のようなピークのない 平坦な分布にすることで最大伝送エネルギーを増すこと が可能である2,5,6).

コア内部については, 損傷しきい值の低い入射端面で損 傷を発生しなければコア内部でも損傷は発生しないはず であるが, 入射光がコア内部で小さなスポットに集光する ことで損傷を引き起こすと考えられる，従って,コア内部 での損傷を防ぐためにはコア内部でレーザー光が集光し ないよう配慮する必要がある。通常, 入射光は入射端面の 手前で焦点を持つように集光し, 拡散する状態で光ファイ バに入射する。

光ファイバの出射端面では入射端面に比ベビーム径が 大きく,また,レーザー光のエネルギー密度分布は伝送中 に十分均一化されるため入射端面に比べ損傷は起こりに <w.

\section{2 ビームホモジナイザの適用}

光ファイバ入射端面でレーザー光のエネルギー密度を 平坦にするとともにコア内部での集光を防ぐための光 ファイバ入射光学系に, 主にエキシマレーザー加工で利用 されているビームホモジナイザの原理を適用した. Fig.2 に示すように, 光ファイバ入射光学系はレーザービームを 拡大するためのビームエキスパンダ, レーザービームを分

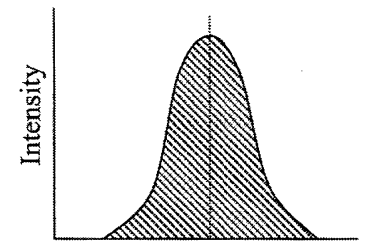

Beam position

(a) Gaussian type

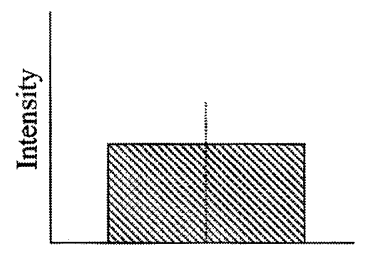

Beam position

(b) Flat-top type
Fig.1 Comparison of two types of laser beam profile for fiber delivery.

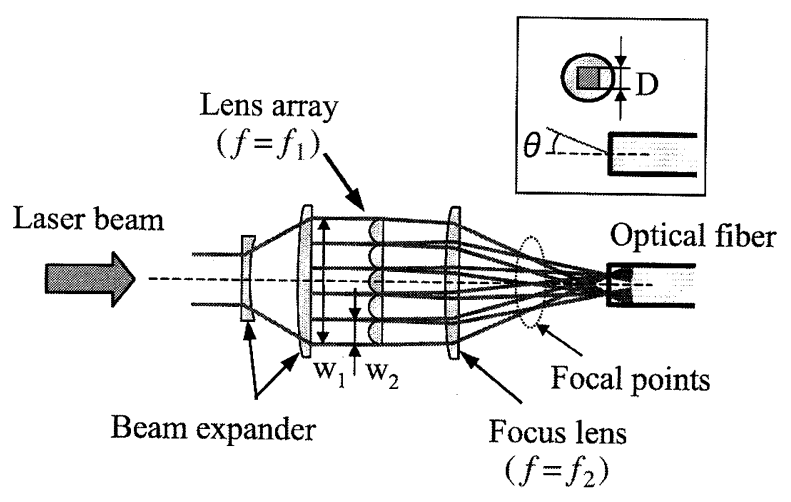

Fig.2 Schematic drawing of incident optics for fiber.
割するためのレンズアレイおよび光ファイバに集光する ための集束レンズから構成されている。レンズアレイに より分割されたレーザービームは光ファイバ入射端面で 一つに重ね合わされるため均一なエネルギー密度分布と なる。また，それぞれのレーザービームは異なる位置に焦 点を持つため光ファイバのコア内部で小さなスポットに 集光しにくくなる．さらに, 入射端面より手前の空気中に おいてもブレイクダウンを起こしにくくなる.

ビームホモジナイザの集光面でのスポットサイズDおよ び周縁光線が光軸となす角度 $\theta$ は, レンズの収差やレンズア レイと集光レンズの距離を無視すれば以下の式により簡 易的に求めることができる。ここで, $f_{1}$ と $f_{2}$ はそれぞれレン ズアレイおよび集光レンズの焦点距離, $w_{1}$ および $w_{2}$ はレン ズアレイに入射するレーザービームの幅とレンズアレイ を構成する小レンズの幅である。

$$
D=w_{2} \times f_{2} / f_{1} \quad \tan \theta=\left(w_{1} / f_{2}+w_{2} / f_{1}\right) / 2
$$

Fig.3に集光位置での均一化したエネルギー密度の空間 分布の例を示す。

\section{3 光ファイバ伝送試験}

Fig.4に伝送試験に用いた装置の構成を示す。光源にQス イッチ式Nd:YAGレーザーの第2高調波(波長 $532 \mathrm{~nm}$, パルス 幅 $5 \mathrm{~ns}$, 繰り返し $10 \mathrm{~Hz}$ )を用い, コア径 $0.6 \mathrm{~mm}$ のSI型マルチ モード石英ファイバ(Fiberguide SFS-600Z)により伝送し た. 光源からのレーザー光はビームアッテネータを用い てエネルギーを調整した。また,ビームスプリッタにより レーザー光の一部を分岐してパワーメータにより出力を モニターするとともに, 光ファイバ出射端においても出射

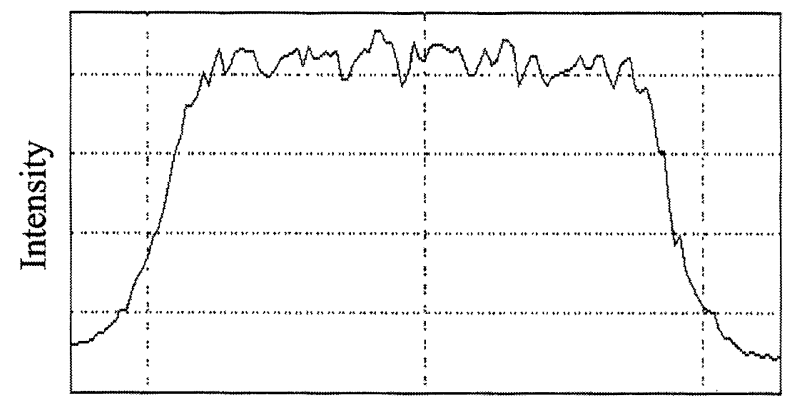

Beam position

Fig.3 Beam profile homogenized on the fiber surface (wavelength: $532 \mathrm{~nm}$, pulse duration: $5 \mathrm{~ns}(\mathrm{FWHM})$ ).

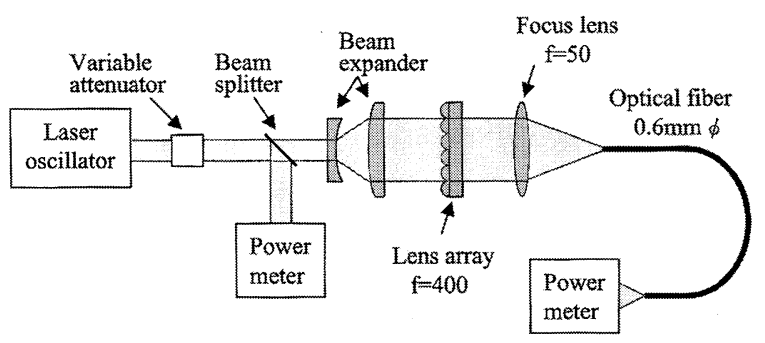

Fig.4 Experimental setup for fiber delivery using beam homogenizer. 
光の出力をパワーメータによりモニターした.

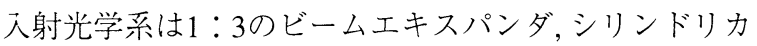
ルレンズを直交して組み合わせた $7 \times 7$ のレン゙アレイ $(f=$ $400 \mathrm{~mm})$ および集光レンズ $(f=50 \mathrm{~mm})$ で構成されている. ビームエキスパンダとレンズアレイの間にはレンズアレ イに対応した7×7の円形のアパーチャを置き, 入射端面で 円形になるよう集光した，光ファイバの端面は損傷しき い值を高めるため研磨せずに折ったままで使用した7). 光 ファイバへの入射条件としては, 光ファイバのコア径と開 口数を $d_{\mathrm{f}}$ おび $N A_{\mathrm{f}}$ とすると, 光ファイバ入射端面での集光 スポット径 $d_{\mathrm{i}}$ と開口数 $N A_{\mathrm{i}}$ は以下の条件を満足する必要が ある*。そこで, 入射端面での集光スポット径は $d_{\mathrm{f}}=$

$$
\begin{aligned}
& d_{\mathrm{i}}=0.7 d_{\mathrm{f}} \text { for } d_{\mathrm{f}} \leqq 0.6 \mathrm{~mm} \\
& d_{\mathrm{i}}=d_{\mathrm{f}}-0.2 \mathrm{~mm} \text { for } d_{\mathrm{f}}>0.6 \\
& 0.3 N A_{\mathrm{f}} \leqq N A_{\mathrm{i}} \leqq 0.9 N A_{\mathrm{f}}
\end{aligned}
$$

$0.6 \mathrm{~mm}$ よ $d_{\mathrm{i}}=0.4 \mathrm{~mm}$ に, 開口数は $N A_{\mathrm{f}}=0.22$ より $N A_{\mathrm{i}}=0.2$ とした。

コア径0.6mmのファイバを用いた伝送試娩り結果, 最大

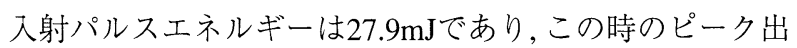
力は $5.6 \mathrm{MW}$, 入射端面の出力密度は $44 \mathrm{TW} / \mathrm{m}^{2}\left(4.4 \mathrm{GW} / \mathrm{cm}^{2}\right)$ であった。

さらに,コア径1.5mmの石英ファイバ(Fiberguide SFS1500Z)を用いて伝送試験を行った。ビームエキスパンダ の拡大率を $1: 4$ に, 集光レンズの焦点距離を $f=150$ に変更 した. 光源の最大出力に制限があることから円形に集光 するためのアパーチャを取り除いたため, 光ファイバの入 射端面での集光の形状は $0.81 \mathrm{~mm} \times 0.81 \mathrm{~mm}$ の四角形となっ た。伝送試験の結果, 最大入射パルスエネルギーは $138 \mathrm{~mJ}$, この時のピーク出力は $27.6 \mathrm{MW}$, 入射端面の出力密度は $42 \mathrm{TW} / \mathrm{m}^{2}\left(4.2 \mathrm{GW} / \mathrm{cm}^{2}\right)$ であり, コア径0.6mmのファイバと ほほ同等の結果が得られた。

\section{3. 光ファイバ伝送技術の応用}

\section{1 パルスレーザーの応用分野}

レーザー装置の高機能化と小型化に伴い, 加工, 表面改 質, 超微粒子の創製, 成膜などの応用開発が急速に進展し ている8 . パルスレーザーのファイバ伝送が可能になる と, 応用範囲の更なる拡大が期待できる，特に，遠隔での 操作性が要求される既存構造物の検査・補修技術は, ファ イバ伝送のメリットが大きく, レーザー超音波探傷(レー ザーUT) ${ }^{9)}$,レーザークリーニング10,11，レーザーブレイク ダウン分光分析(LIBS) ${ }^{12}$, レーザーピーニング13.14)などへ の応用が期待されている.

これらの技術は光源としてQスイッチNd:YAGレーザー (基本波または第2高調波)を用いることが多く, 石英系ファ イバによる伝送が可能な波長領域である。必要とされる エネルギー密度は, レーザーピーニングおよびLIBSで $10^{5} \mathrm{~J} /$ $\mathrm{m}^{2}$ のオーダーであり,レーザーUTおよびレーザークリーニ
ングでは $10^{2} \sim 10^{3} \mathrm{~J} / \mathrm{m}^{2}$ 程度である. 従って,レーザーピー二 ングおよびLIBSへの適用が最も困難であることが分か る.そこで,レーザーピーニングへの光ファイバ伝送技術 の適用について検討した結果を以下に述べる.

3.2 レーザーピーニングの原理と適用の目的

レーザーピーニングは水中でパルスレーザーを金属表 面に照射し, 材料表面で発生するレーザープラズマの衝撃 力により材料の表面処理を行って疲労強度の向上や応力 腐食割れ防止をはかる技術である.

Fig.5にレーザーピーニングの原理を示す. 水中透過性 の良い可視光の短パルスレーザーを水中で集光して材料 に照射する，レーザー光のエネルギー密度が十分高い場 合, 材料表面では材料自身がプラズマ化し急速に澎張する が, 水中では水の閉じ込め効果により膨張が抑制されプラ ズマの圧力は数GPaに達する。この圧力は衝撃波となって 材料中を伝播し塑性変形を引き起こすが, 周囲からの弾性 拘束により圧縮残留応力が材料内部に形成される.

筆者らはFig.6に示すレーザーピーニング施工装置を開 発し, 原子炉の炉内構造物である炉心シュラウド溶接線の 熱影響部の応力改善に適用した。レーザーピーニング施 工により材料表面の残留応力を引張状態から圧縮状態に 変換することで応力腐食割れの発生を未然に防止するこ とができる。この装置ではQスイッチ式Nd:YAGレーザー の第2高調波(波長532nm, パルス幅10ns以下, 繰り返し60ま たは $120 \mathrm{~Hz}$ )を水密構造の中空パイプの中をミラーで反射 しながら最大約 $40 \mathrm{~m}$ 先の施工ヘッドまで伝送しており, レーザー光の照射位置を $0.1 \mathrm{~mm}$ の精度でリアルタイムに制 御するために高機能なビームアライメント機構を新たに 開発した。しかし, 今後さらに狭险で複雑な形状の炉底部 や配管内面などへ適用する上でレーザー光の光ファイバ 伝送化が望まれている．光ファイバは振動や温度などの 周囲環境の影響を受けにくく構造が柔軟であるため, シス テムの簡素化と適用範囲の拡大が可能である.

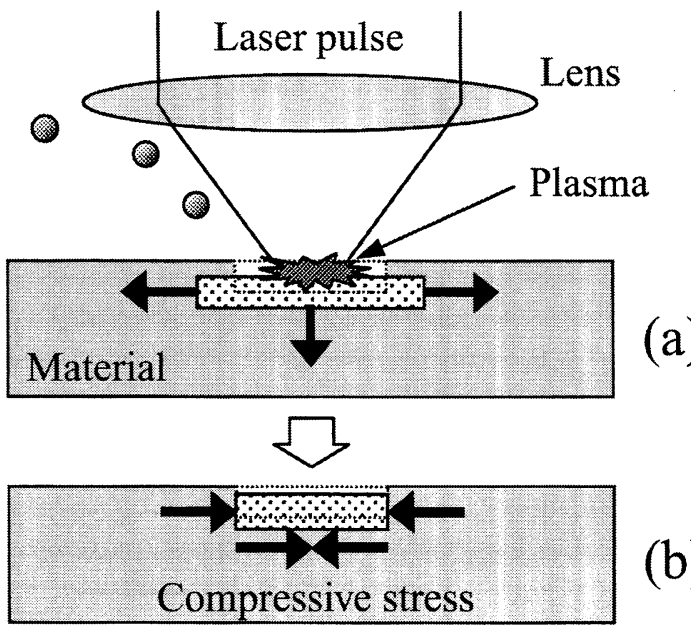

Fig.5 Fundamental process of laser peening: during (a) and after (b) laser irradiation. ${ }^{14)}$

* Fiberguide Industry; Inc.: Application Note. 


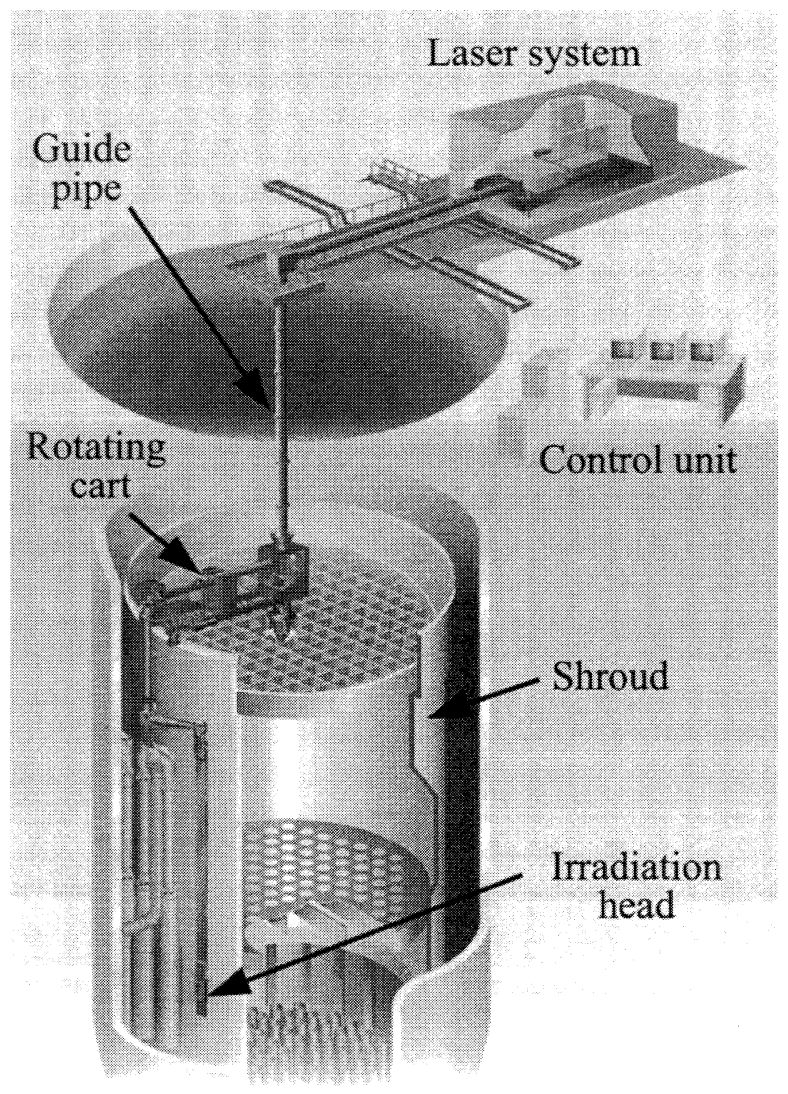

Fig.6 Concept of laser peening system for BWR core shroud. ${ }^{14)}$

\section{3 応力改善試験}

コア径 $1.5 \mathrm{~mm}$, 長さ $5 \mathrm{~m}$ の石英ファイバ(Fiberguide SFS1500Z)を介して伝送したレーザー光により応力改善試験 を行った．光源および入射光学系は伝送試験と同一の体 系であり,光ファイバからの出射光の集光光学系および施 工装置はFig.7に示した $f=120$ および $f=50$ の 2 枚のレンズ と試験水槽で構成されている。集光されたレーザー光は 水槽の光学空を透過した後，照射ノズルから水槽中の SUS304試験片に照射される。試験片はXYステージにより 駆動されており，XYステージは試験片中央の $12 \mathrm{~mm} \times$ $12 \mathrm{~mm}$ の範囲に均一にレーザー光が照射されるよう計算機 により制御されている。 Fig.8に試験片の外形とレーザー 光の照射方法を示す．試験片表面ではレーザー光が照射 されると気泡やプラズマの残渣が発生するため, 光軸と同 軸に照射ノズルから水を噴射してこれらを除去した。試 験片には原子炉内の中性子線による照射硬化を模擬する ため20\%冷間加工を施し, 表面は溶接時の熱影響を模擬す るためグラインダ加工により引張残留応力を付与した.

レーザー光のパルスエネルギーは光ファイバ出射端で パワーメータにより測定し $100 \mathrm{~mJ}$ (ピーク出力 $20 \mathrm{MW}$ )とし た。このときの入射パルスエネルギーは $125 \mathrm{~mJ} ゙$ あり,伝 送効率は $80 \%$ であった。照射面での集光スポット径は $0.7 \mathrm{~mm}$ で, $1 \mathrm{~mm}^{2}$ あたり100パルスを均一に照射した。

施工後の表面残留応力はX線残留応力測定法により測定 し,電解研磨と測定を交互に繰り返すことで深さ方向の応

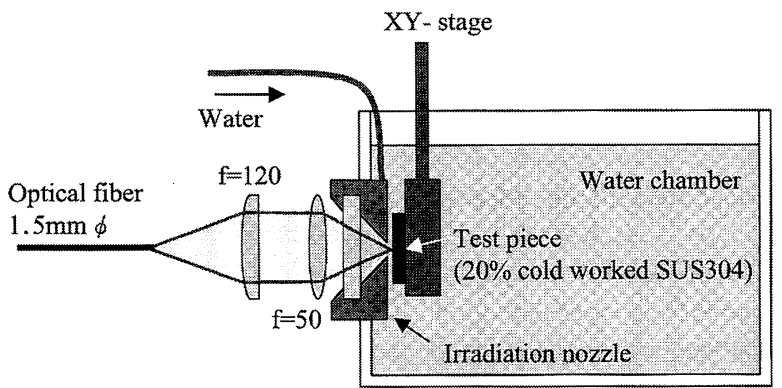

Fig.7 Experimental setup for laser peening.

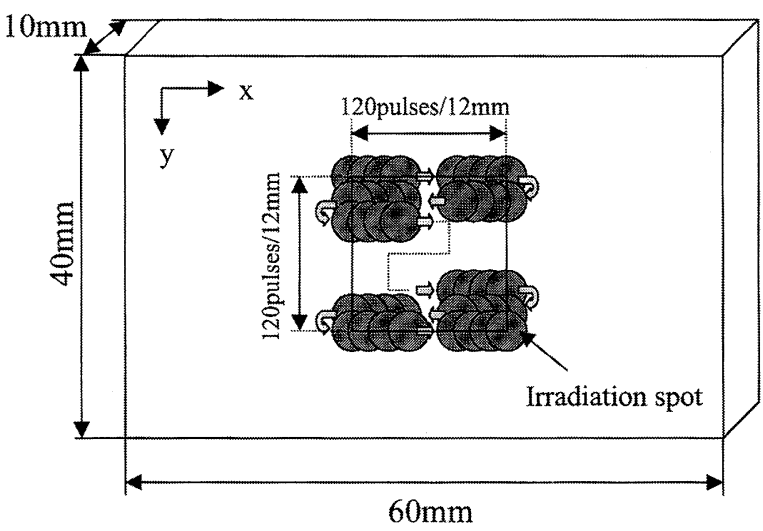

Fig.8 Dimensions of a SUS304 test sample and sequence of pulse laser irradiation.

力分布を求めた. Fig.9に未施工および施工後の材料の残 留応力分布を示す. レーザーの走査方向をX方向, それと 垂直な方向をY方向として両方向の残留応力を測定した. その結果, 光ファイバ伝送光を照射したことにより表面か ら深さ $0.8 \mathrm{~mm}$ 以上まで圧縮残留応力が形成され, 応力改善 効果が確認された.

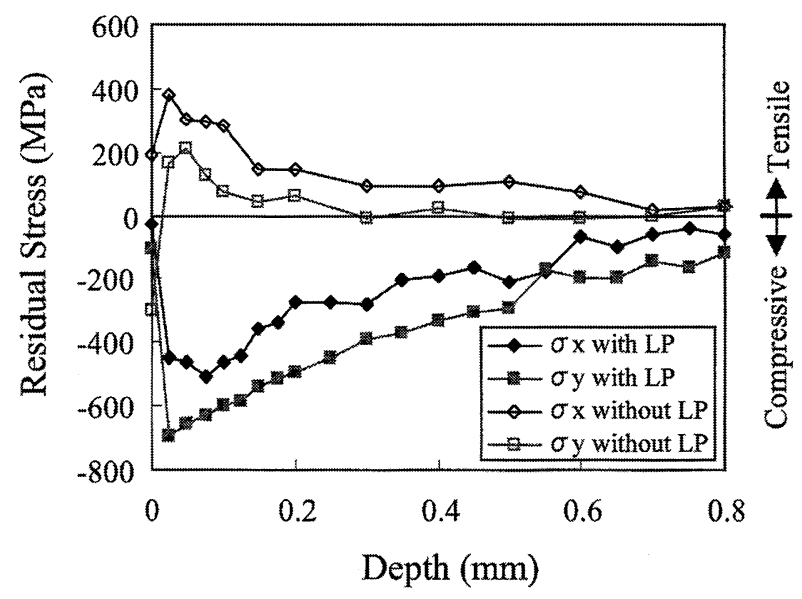

Fig.9 Residual stress profile of test samples with and without laser peening by fiber-delivered laser pulses (test sample: $20 \%$ cold worked SUS304, pulse energy: $100 \mathrm{~mJ}$, spot diameter: $0.7 \mathrm{~mm}$, pulse density: 100 pulse/mm²). 


\section{4. 結 言}

ビームホモジナイザを適用した入射光学系を採用した ことによりピーク出力 $20 \mathrm{MW}$ の高出力パルスレーザー光を 光ファイバにより伝送し, パルスレーザーの応用分野で最 もファイバ伝送が困難であったレーザーピーニング技術 に適用できることを金属材料の応力改善試験により確認 した。また，今回報告した高出力パルスレーザー光の光 ファイバ伝送技術は,パルスレーザー光を利用したレー ザー超音波探傷技術やレーザークリーニング技術, あるい はレーザーブレイクダウン分光による分析技術等の様々 な分野への適用が期待できる。

\section{参考文献}

1）松浦祐司,宮城光信：レーザー研究 27 (1999) 173.

2) H. Kar, J. Helfmann, K. Dörschel, G. Müller, O. Müller, H. Ringelhan, and B. Schaldach: SPIE 1067 (1989) 223.
3) N. Bloembergen: IEEE J. Quantum Electronics QE-10 (1974) 375.

4) S. W. Allison, G. T. Gillies, D. W. Magnuson, and T. S. Pagano: Appl. Opt. 24 (1985) 3140.

5) W. M. Trot and K. D. Meeks: J. Appl. Phys. 67 (1990) 3297.

6) B. Richou, I. Schertz, I. Gobin, and J. Richou: Appl. Opt. 36 (1997) 1610.

7) F. Wondrazek and F. Frank: Laser und Optoelektronik 20 (1988) 62.

8）電気学会レーザアブレーションとその産業応用調查専門委員 会編：レーザアブレーションとその応用 (コロナ社, 1999).

9) 落合 誠, 仏円 隆, 成瀬 克彦, 平澤泰治：日本原子力学会 1999 年春の年会要旨集 II (1999) p.269.

10）日塔光一, 山口恭志, 田村 俊幸, 福島 正, 松林 義和, 松井政 雄：火力原子力発電 $\mathbf{5 0}$ (1999) 711 .

11）大橋克明, 蘆立修一, 黑澤潔, 中根昌代, 高田 淳, 岡崎 幸基, 芦部 楠夫, 小長井 主税, 本吉 和仁：1999年電気学会全国大会 講演論文集 (1999) p.7.

12）中根昌代, 中山邦彦, 芦部 楠夫, 小長井主税, 本吉 和仁, 鈴木 典子：日本原子力学会1998年秋の大会予稿集 I (1998) p.49.

13）佐野雄二, 依田 正樹, 向井 成彦, 小畑 稔：レーザー研究 26 (1998) 793.

14) Y. Sano, M. Kimura, N. Mukai, M. Yoda, M. Obata, and T. Ogisu: Proc. Int. Forum AHPLA'99, SPIE 3888 (Osaka, 1999) p.33. 